in 1903 , and the gold medal of the Royal Astronomical Society a second time in 1908 .

No biographical notice of Sir David Gill would be complete without some reference to his striking personality. His force of character enabled him to triumph over difficulties and carry out great projects. His enthusiasm and tenacity of purpose communicated themselves to his colleagues and assistants, and supported them and him in the arduous details inseparable from astronomical enterprise. But he never lost in these details a clear view of the ultimate purpose of his work. As an astronomical observer he was unsurpassed, the pleasure of making every measurement as accurately as he was able counterbalancing the tedium of making observations of similar character night after night. His engineering skill stood him in good stead, and the perfecting of his instruments was a constant source of delight to him. His administrative success was due in large measure to the confidence he inspired in his staff, and their regard for him both as an astronomer and as a friend.

His health had been excellent since his return to London, and his large circle of friends hoped that he would be with them for many years. $\mathrm{He}$ was suddenly seized with pneumonia in December, 1913, and passed away on January 24, after an illness of six weeks. We would tender to Lady Gill our respectful sympathy in her sudden bereavement.

F. W. D.

Sir David Gill was laid to his rest on Wednesday, January 28, the funeral being at St. Machar Cathedral, Aberdeen. A memorial service was held at St. Mary Abbot's, Kensington, and was attended by a large number of personal friends as well as representatives of institutions of science and learning, among the latter being:--Prof. Forbes (Edinburgh University), Sir William Crookes and Sir Archibald Geilie (Royal Society), Sir Norman Lockyer (British Science Guild), Lady Lockyer (the Hill Observatory, Salcombe-Regis), Dr. F. W. Dyson, Astronomer Royal, Major E. H. Hills (Royal Astronomical Society), Colonel E. E. Markwick (British Astronomical Association), Prof. H. H. Turner (Oxford University, and, with Major MacMahon and Mr. O. J. R. Howarth, the British Association), Mr. H. F. Newall (Cambridge University), Major Leonard Darwin (Royal Geographical Society), Dr. R. T. Glazebrook (National Physical Laboratory and Optical Society), Dr. W. N. Shaw (Meteorological Office), Dr. P H. Cowell (Nautical Almanac Office), M. Jules Baillaud (representing the director of the Paris Observatory), Dr. A. E. H. Tutton (Mineralogical Society), Mr. W. H. Low (Cape Town Caledonian Society), Captain Lyons (the Science Museum), and Prof. Kapteyn (Groningen University).

DR. R. T. OMOND.

THE death of Dr. R. T. Omond at his house in Edinburgh on the morning of January 27 removes from us one whose name will be permanently associated with the famous Ben Nevis Observatory. Under his direct superintendence on that cloud-capped summit, hourly observations of the important meterological elements were taken night and day for about ten years following i 884 ;

NO. 23 IO, VOL. 92] and although his health prevented him doing the observational work for the remaining ten years of the great experiment, his whole mind was given to the completion of the undertaking. He continued as honorary superintendent; and devoted his time and energies to the reduction and discussion of the wealth of observations which had accumulated.

Dr. Omond was associated with Dr. Alexander Buchan in the preparation of the earlier of the four quarto volumes (Trans. R.S.E., vols. 36, 42, $43,44)$ in which the observations are tabulated; but of the later volumes he had necessarily sole charge, and from the very beginning, indeed, the main labour of tabulation and proof correction rested with him. In addition to the tabulated observations of pressure, temperature, humidity, wind, rain, snow, \&c., these volumes contain discussions and papers on various meteorological questions. There is also reproduced in detail the daily log-book of the observers, a fascinating and suggestive scientific document, containing, inter alia, descriptions of halos, glories, and coronæ, on which Omond himself contributed two papers to the Royal Society of Edinburgh. His principal scientific papers are published in the Ben Nevis volumes already mentioned, and in the Journal of the Scottish Meteorological Society.

Dr. Omond was educated at the Edinburgh Collegiate and at the University of Edinburgh. He did not follow any of the ordinary courses qualifying for degrees, but devoted himself mainly to study of physics under Prof. Tait; and to geology under Sir Archibald Geikie. He was, indeed, Tait's right-hand man in the investigations on the compressibility of fluids which arose out of the testing of the Challenger thermometers. He became a Fellow of the Royal Society of Edinburgh in 1884 , was awarded the Keith Prize in I 892 for his Ben Nevis work, and served one term (I9OI-4) on the Council. The University of Edinburgh conferred on him the honorary degree of Doctor of Laws at the summer graduation of I9I3. Hampered though he was latterly by a serious malady, he put through an immense amount of work, and retained to the end the bright, cheerful, unselfish spirit which endeared him to his many friends.

\section{G. Knotr.}

\section{NOTES.}

WE record with much regret the death, on February $\mathrm{I}$, in his eighty.fourth year, of Dr. Albert Günther, F.R.S., formerly leeper of the zoological department of the British Museum (Natural History).

The Postmaster-General has appointed a Committee to inquire into systems of high-speed telegraphy and to report thereon. The Committee will consist of Captain Norton, M.P., Assistant Postmaster-General (chairman), Sir John Gavey, C.B., Mr. J. Lee, Mr. W. M. Mordey, Mr. A. M. Ogilvie, C.B., Mr. W. Slingo, and Mr. A. B. Walkley. Anyone desirous of giving evidence before the Committee should com- 